\title{
QTL detection for physicochemical characteristics of cashew apple
}

\author{
Francisco Herbeth Costa dos Santos ${ }^{1 *}$, José Jaime Vasconcelos Cavalcanti ${ }^{2}$ and Fanuel Pereira da Silva ${ }^{1}$
}

Received 15 March 2010

Accepted 22 August 2010

\begin{abstract}
The identification of quantitative trait loci $(Q T L)$ and marker-assisted selection have aroused great interest in breeding programs aiming at fruit quality. The objective of this study was to detect QTL related to the quality of the cashew apple. The physicochemical characteristics oligomeric phenolics, total soluble solids, total titrable acidity and vitamin $C$ contents were analyzed in the mapped cashew population. QTL were detected by QTL interval and multiple QTL mapping. The results showed high phenotypic variation in the segregating $F_{1}$ generation for all traits. Eighteen QTL associated with cashew quality were identified: three for oligomeric phenolics, five for total soluble solids, six for total acidity and four for vitamin C. QTL are promising for marker-assisted selection since they have the greatest phenotypic effects and contribution to phenotypic variation.
\end{abstract}

Key words: Anacardium occidentale, breeding, cashew apple quality, molecular markers.

\section{INTRODUCTION}

Clones of early dwarf cashew (Anacardium occidentale $\mathrm{L}$.) have greatly impacted cashew cultivation in the Northeastern region of Brazil since they are more productive, earlier, shorter, easily harvested and have uniform cashew nuts and apples (Barros et al. 2002). These factors have contributed to an increased consumption of fresh cashew apple. Despite this advance, consumption is still limited, due to several factors, such as the astringent taste along with the high phenolic content of cashew apple (Crisóstomo et al. 2002).

To meet the demand for new varieties with better fruit quality, breeders need new methods and strategies to increase efficiency and reduce the time required for the development of a new variety. Most plant traits of economic importance, e.g., grain yield, can be classified as quantitative. Even some traits with simpler inheritance, such as disease resistance, can be considered "semiquantitative", since the trait expression is controlled by a few genes and one major gene, with several modifiers (Stuber et al. 1999). Conventional breeding can be accelerated by direct identification and manipulation of quantitative trait loci (QTL) in a system based on molecular markers co-segregating with the trait of interest (Cristofani et al. 1999).

Molecular markers are an efficient tool for indirect selection in plant breeding. They are used for introgression of monogenic traits, e.g., disease resistance (Singh et al. 2001). For polygenic traits, several QTL are being mapped and their individual effects estimated (Kearsey and Farquhar 1998). The great potential of using molecular

\footnotetext{
${ }^{1}$ Universidade Federal do Ceará, Departamento de Fitotecnia, CP 6035, 60.451-970, Fortaleza, CE, Brazil. *E-mail: herbeth.santos@gmail.com

${ }^{2}$ Embrapa Algodão, CP 174, 58.428-095, Campina Grande, PB, Brazil
} 
markers for breeding lies in the virtually unlimited number, easy identification and behavior as "traits" of simple and predictable inheritance, unaffected by the environment, which may be useful to select desirable genotypes for breeding (Alzate-Marin et al. 2005).

It should be noted that a QTL analysis must begin with the construction of a genetic linkage map with sufficient density of molecular markers for an adequate genome coverage underlying advanced genetic studies that deepen the understanding of gene inheritance, identification and isolation (Ribeiro et al. 2005, Kenis and Keulemans 2005). Genetic maps for cashew apple were developed by Cavalcanti and Wilkinson (2007), using a segregating $F_{1}$ population with 85 plants of the cross CCP 1001 x CP 96. These maps are a basis for the identification of QTL related to economically important traits.

The markers can be used in early stages (seedling) for the selection of plants with favorable combinations of several economically interesting traits. Marker-assisted selection is particularly promising in cashew improvement, due to the juvenile period of this species and the polygenic nature of the fruit quality traits. These represent the narrowest bottleneck in conventional breeding programs, since the progenies of crosses must be maintained for a long time before fruit quality can be assessed. In this sense, it is expected that some specific problems, such as a reduction in phenolic content and/or increase in the percentage of soluble solids and vitamin $\mathrm{C}$ of the peduncle can be solved more quickly and with lower operating costs by the use of molecular markers linked to QTL for cashew quality. The purpose of this study was to identify QTL related to physicochemical quality of cashew apple for a possible application in marker-assisted selection in cashew apple breeding programs.

\section{MATERIAL AND METHODS}

The cashew used for QTL mapping belonged to a full-sib $\mathrm{F}_{1}$ progeny population, consisting of 85 plants from controlled crosses of CCP 1001 x CP 96, crossed in September 2000 and planted in March 2001. The female parent, CCP 1001, is a commercial dwarf cashew clone and the male parent, CP 96, a giant cashew genotype. Both belong to the same cashew species. The parents were chosen to ensure a maximum contrast in plant height and resistance to the disease anthracnose (Colletotrichum gloeosporioides) and black mold (Pilgeriella anacardium).
The experiment was conducted in the Experimental Field of Pacajus of Embrapa Agroindústria Tropical, in Pacajus, CE (lat $4^{\circ} 10^{\prime} \mathrm{S}$, long $38^{\circ} 27^{\prime} \mathrm{W}$, alt $60 \mathrm{~m}$ asl). The cashew apples were hand-harvested, to avoid bruising or early deterioration of the fruits. Since the plants of the $F_{1}$ generation were segregating for fruiting period, the apples were harvested from October through November 2006, which is the peak production period. Samples of 15 cashew apples per plant were harvested at commercial maturity and transported on foam-lined trays to the Laboratory of Physiology and Postharvest Technology of Embrapa Agroindústria Tropical, Fortaleza, CE, for post-harvest analyses. Of the original $85 \mathrm{~F}_{1}$ plants used to create genetic maps of the parents, 66 plants produced a satisfactory number of peduncles and were included in the analysis to evaluate the content of oligomeric phenolics, soluble solids, total acidity and vitamin $\mathrm{C}$ of the cashew apple. The parents CCP 1001 and CP 96 were evaluated as controls, as well as clone CCP 76, the most cultivated for fresh fruit market.

The pulp obtained from peduncles homogenized in a domestic blender was evaluated as described below: a) determination of oligomeric phenolics using a $50 \%$ methanol extraction liquid according to a methodology described by Reicher et al. (1981). The readings were taken on a spectrophotometer at $720 \mathrm{~nm}$ and results expressed in percentages; b) Measurement of soluble solids with a refractometer and expressed as ${ }^{\circ} \mathrm{Brix}$ as recommended by the Association of Official Analytical Chemists (AOAC 1992); c) Total acidity determined by a titration potentiometer with $\mathrm{NaOH}$ solution $(0.1 \mathrm{~N})$, as recommended by the Institute Adolfo Lutz (IAL 1985), in percentage of malic acid and d) Measurement of vitamin $\mathrm{C}$ by titration with 2,6-dichloro-phenol indophenols, as described by Strohecker and Henning (1967), in mg $100 \mathrm{~g}^{-1}$.

The broad-sense heritability, the coefficient of genetic and environmental variation as well as the genotypic variance were estimated for each trait. The Pearson correlation coefficient was estimated to determine the degree of association between traits. Analyses were performed using Genes software (Cruz 2001).

The QTL mapping was performed using analysis of Multiple QTL Mapping (MQM) (Jansen 1993, 1994, Jansen and Stam 1994), which is an extension of the Interval Mapping (IM) analysis (Lander and Botstein 1989). Analyses were performed using all markers of the genetic linkage maps developed by Cavalcanti and Wilkinson (2007). The maps were obtained using the methodology 
of pseudo-testcross with 205 genetic markers, 194 of which were AFLP and 11 SSR. Two maps representing each of the parental genomes (CCP 1001 and CP 96) were constructed separately. The QTL were detected and mapped using software MapQTL 5 (Van Ooijen 2004).

The interval mapping analysis was performed to identify QTL with significant main effects and the markers in these regions were used as co-factors in the subsequent analysis of multiple QTL mapping to increase accuracy in detecting QTL that occur in adjacent intervals in the same linkage group, as recommended by Van Ooijen (2004). LOD score peaks indicate the presence of a QTL in a segment of the map. A critical LOD score of 3.0 was used as basis for the identification of candidate QTL. This value indicates that the occurrence of QTL-marker linkage is 1000 times more likely than of independent segregation. The QTL detected in this way were described by the markers closest to the corresponding QTL region. The QTL position was defined using MapChart software (Voorrips 2002), with confidence intervals of 1.0 and 2.0 LOD score, corresponding to a coverage probability of the QTL of approximately 95 $\%$ (Van Ooijen 2004). The proportion of phenotypic variation explained by the trait-marker association was estimated by the coefficient of determination $\left(\mathrm{R}^{2}\right)$. The phenotypic effect $(\mathrm{PhE})$ of the QTL-associated marker was estimated by the difference between populations with and without the presence of the marker (Broman 2001).

\section{RESULTS AND DISCUSSION}

\section{Physicochemical characteristics of the peduncles}

The distribution of the traits oligomeric phenolics, soluble solids, total acidity and vitamin $\mathrm{C}$ was continuous normal in the population, according to the Lilliefors test ( $\mathrm{p} \leq 0.01$ ), as expected by the complex pattern of trait inheritance. The distribution of phenotypic and average values of traits for each parent are shown in Figure 1. Transgressive segregants were observed for the four traits in the population. The analysis of variance evidenced genetic diversity in the population for the traits under study (Table 1). Low coefficients of experimental variation and high ratio $\mathrm{CVg} / \mathrm{CVe}$ in the analysis of the four characteristics, indicated, respectively, excellent experimental accuracy and that much of the total variation is a consequence of genetic variation. The broad-sense heritability, estimated for oligomeric phenolics, soluble solids, total acidity and vitamin $\mathrm{C}$ of the peduncles of the population, was high and indicated the potential of the cashew population for genetic mapping at the molecular level, aiming to identify QTL for economically important traits as well as the possibility of selecting superior genotypes for the improvement of these traits.

The correlation coefficients were calculated to determine the degree of association between the traits, since it was noted that the map position of QTL for correlated traits is often similar (Paterson et al. 1991). The correlation coefficients were significant for all trait combinations (Table 2). The traits vitamin $\mathrm{C}$ content and oligomeric phenolics were positive and significant $\left(\mathrm{r}=0.71^{* *}\right)$. This fact complicates the breeding process, because the genotypes with high vitamin $\mathrm{C}$ levels (desirable) also have a high content of oligomeric phenolics (undesirable), which indicates an increased astringent taste, a fact leading to consumer rejection, particularly in the case of market for fresh cashew. These results indicate the possibility of genetic correlation, which could be confirmed by the QTL analysis, i.e., by observing coincidences between QTL for correlated traits.

\section{QTL analysis}

The QTL analysis provides important information in support of different breeding programs in plants and animals. This study represents a QTL analysis for economically important traits related to cashew apple quality and is the first on QTL associated with traits of oligomeric phenolics, soluble solids, total acidity, and vitamin $\mathrm{C}$.

The results of the QTL analyses are presented in Table 3. Based on the analysis of multiple QTL mapping, 18 loci linked to QTL called "candidate QTL" were detected, since they should be assessed prior to use in breeding programs. In other words, the selection efficiency of these candidate QTLs should be determined in other cashew populations for the trait to be improved, which is a subject of future studies. Three markers significantly associated with QTL were identified for oligomeric phenolics, five for total soluble solids, six for total acidity, and four for vitamin C.

The proportion of variation explained by a single QTL trait is probably the greatest obstacle to the implementation of marker-assisted selection. In this study, the percentage range of phenotypic variation $\left(\mathrm{R}^{2}\right)$ explained by the associations of marker loci and QTL was 3.90 $11.66 \%$ for oligomeric phenolics, $3.48-16.29 \%$ for soluble solids, $4.17-13.08 \%$ for total acidity, and $9.19-15.36 \%$ for 
FHC Santos et al.
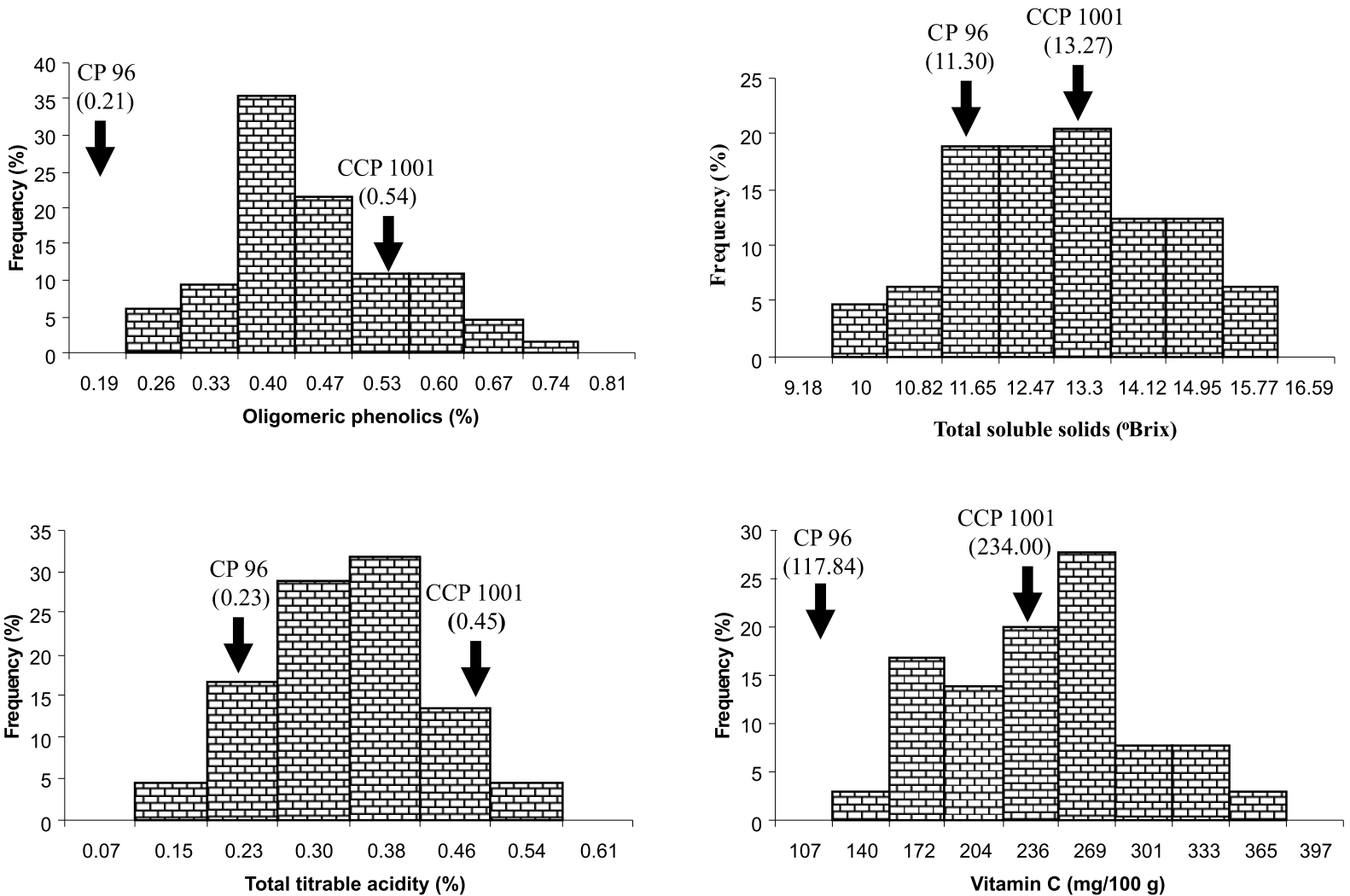

Figure 1. Frequency distribution of 66 plants of the segregating $F_{1}$ generation of the cross CCP 1001 x CP 96 in terms of oligomeric phenolics, total soluble solids, total titrable acidity and vitamin C in cashew apples. Arrows indicate the phenotypes of the parents. CCP 1001 - female parent; CP 96 - male parent.

Table 1. Analysis of variance, observed means and genetic parameters of the traits evaluated in 66 plants of the segregating $F_{1}$ generation of the cross CCP $1001 \times$ CP 96, and in the three controls (CCP 76, CCP 1001 and CP 96) ${ }^{1}$

\begin{tabular}{|c|c|c|c|c|c|}
\hline \multirow{2}{*}{ Sources of variation } & \multirow{2}{*}{ df } & OPh & TSS & TTA & VC \\
\hline & & \multicolumn{4}{|c|}{ Mean squares } \\
\hline Treatments & 68 & $0.0380^{* *}$ & $6.1245^{* *}$ & $0.0309 * *$ & $9203.5675^{* *}$ \\
\hline F 1 genotypes & 65 & $0.0356 * *$ & $6.2726 * *$ & $0.0303 * *$ & $8847.0830 * *$ \\
\hline Controls & 2 & $0.0849 * *$ & $3.3233 * *$ & $0.0492 * *$ & $11805.2354 * *$ \\
\hline $\mathrm{F}_{1}$ genotypes $\mathrm{x}$ controls & 1 & $0.0966^{* *}$ & $2.1046^{* *}$ & $0.0316^{* *}$ & $27171.7257 * *$ \\
\hline \multirow[t]{2}{*}{ Error } & 138 & 0.0013 & 0.0784 & 0.0003 & 46.4134 \\
\hline & & \multicolumn{4}{|c|}{ Observed means } \\
\hline General mean & & 0.46 & 12.97 & 0.36 & 243.35 \\
\hline Mean of $F_{1}$ genotypes & & 0.47 & 12.99 & 0.36 & 245.79 \\
\hline \multirow[t]{2}{*}{ Control mean } & & 0.36 & 12.50 & 0.30 & 189.61 \\
\hline & & \multicolumn{4}{|c|}{ Genetic parameters } \\
\hline$\hat{\sigma}_{g}^{2}$ & & 0.01 & 2.06 & 0.01 & 2933.56 \\
\hline $\mathrm{CVg}$ & & 22.97 & 11.06 & 27.83 & 22.04 \\
\hline Heritability (\%) & & 96.43 & 98.75 & 99.15 & 99.48 \\
\hline CV (\%) & & 7.73 & 2.16 & 4.49 & 2.80 \\
\hline $\mathrm{CVg} / \mathrm{CVe}$ & & 3.00 & 5.13 & 6.25 & 7.95 \\
\hline
\end{tabular}

${ }^{1} \mathrm{OPh}$ : oligomeric phenolics; TSS: total soluble solids; TTA: total titrable acidity; VC: vitamin C.

$\sigma_{g}^{2}$ : genotypic variance; CVg: coefficient of genetic variation; CVe: coefficient of experimental variation. 
Table 2. Results of the correlation analyses between physicochemical quality components of the cashew peduncle ${ }^{1}$

\begin{tabular}{cccc}
\hline Traits & TSS & TTA & VC \\
\hline OPh & $0.5379^{* *}$ & $0.5908^{* *}$ & $0.7118^{* *}$ \\
TSS & & $0.2523^{* *}$ & $0.4685^{* *}$ \\
$T T A$ & & & $0.5140^{* *}$ \\
\hline
\end{tabular}

${ }^{1} \mathrm{OPh}$ : oligomeric phenolics; TSS: total soluble solids; TTA: total titrable acidity; VC: vitamin $\mathrm{C}$. ** significant at $1 \%$ probability by the $t$ test.

vitamin C. According to Anderson et al. (2007), most QTL studies reveal moderate effects $\left(\mathrm{R}^{2}\right.$ of $\left.10-20 \%\right)$ at one or few loci, while several other loci explain less than $10 \%$ of the variation. This fact was observed in this experiment, where $\mathrm{R}^{2}$ was significant (11 to $16 \%$ ) at only seven QTL: one for phenolics (oph-1f), two for total soluble solids (tss- $1 \mathrm{f}$ and $t s s-3 m$ ), two for total acidity (tta- $1 \mathrm{f}$ and $t t a-4 m$ ) and two for vitamin $\mathrm{C}(v c-1 f$ and $v c-2 f)$. These were considered moderate-effect QTL, with greatest potential for markerassisted selection for the evaluated traits. Most of the identified QTL explained less than $10 \%$ of the variation and were considered small-effect QTL. Similar results have been reported in various QTL studies on fruit quality (Fanizza et al. 2005, Kenis et al. 2008, Santos et al. 2010). The identification of alleles with smaller effects by molecular markers should increase the efficiency of the process, improving the selection gains in a marker-assisted selection program where molecular information is used together with phenotypic data (Melo et al. 2002).

The phenotypic effect was estimated to determine the effect of indirect selection by means of a single marker for each detected QTL. The range of the phenotypic effects of the markers was 9.69 to $19.51 \%$ for oligomeric phenolics, -10.09 to $10.69 \%$ for total soluble solids, -17.95 to $16.71 \%$ for total acidity and 14.19 to 20.76 for vitamin C. These results reflect the importance of the QTL identified in the trait expression and strongly support the existence of true QTL.

QTL clusters of different traits were identified, consistent with results of the correlation analyses. For example, the high correlation coefficient ( $\mathrm{r}>0.71 * *)$ between vitamin $\mathrm{C}$ and oligomeric phenolics was confirmed by the fact that all QTL associated with oligomeric phenolics were located in the same QTL region as vitamin C in linkage groups F2, F4 and M14 (Figures 2 and 3), and important regions in the expression of these traits. These coincidences of QTL for correlated traits confirm the nature of genetic associations. Based on these results it was inferred that these phenotypic characteristics are controlled by closely linked QTL or by the action of QTL with pleiotropic effects. However, the resolution of QTL mapping in this study did not allow a fine-scale dissection of QTL, so there may be more than one close QTL with pleiotropic effects. Similar QTL clusters associated with fruit quality were reported for other fruit species, such as tomato (Lecomte et al. 2004), peach (Quilot et al. 2004) and apple (Kenis et al. 2008). The greatest difficulty caused by this kind of interaction is to distinguish closely linked QTL, which affect various traits of a single QTL with pleiotropic effects.

The results obtained in this study provide support for indirect selection by molecular markers for traits of oligomeric phenols, soluble solids, total acidity, and vitamin C. These can be used, after validation, to identify promising genotypes in the seedling stage, which increases the efficiency of cashew breeding programs by reducing the number of undesirable plants transferred to the field. A reduction of the experimental area, increased genetic gain, and consequently, cost and time savings are therefore expected in the improvement process of this crop. The evaluation of the QTL candidates detected in this study is underway for future use in cashew apple breeding programs. The information obtained here can guide future studies aiming at elite genotypes with improved cashew apple quality.

\section{ACKNOWLEDGEMENTS}

The authors are indebted to Conselho Nacional de Desenvolvimento Científico e Tecnológico (CNPq) for the scholarship and to Embrapa Agroindústria Tropical for supporting the development and execution of the study. 
FHC Santos et al.

Table 3. Description of candidate QTL identified for the physicochemical characteristics of the cashew peduncle in maps of the female (F) and male (M) parents using the multiple QTL mapping method ${ }^{1}$

\begin{tabular}{|c|c|c|c|c|c|c|c|}
\hline Trait & QTL & Linkage group & Position $(\mathrm{cM})^{1}$ & Closest marker & LOD & $\mathbf{R}^{2}(\%)^{2}$ & $\operatorname{PhE}(\%)^{3}$ \\
\hline \multicolumn{8}{|c|}{ Oligomeric phenolics (\%) } \\
\hline & $o p h-1 f$ & $\mathrm{~F} 2$ & 66.83 & $02 \mathrm{CB} 110$ & 3.21 & 11.66 & 19.51 \\
\hline & $o p h-2 f$ & F4 & 111.95 & $13 \mathrm{Ab} 032$ & 4.55 & 3.90 & 9.69 \\
\hline & $o p h-3 m$ & M14 & 0.00 & $13 \mathrm{Bb} 220$ & 3.47 & 7.27 & 13.67 \\
\hline & $t s s-1 f$ & $\mathrm{~F} 1$ & 94.66 & 07CY003 & 4.74 & 12.96 & -10.09 \\
\hline \multicolumn{8}{|c|}{ Total soluble solids ( $\left.{ }^{\circ} \mathrm{Brix}\right)$} \\
\hline & $t s s-2 f$ & F3 & 58.24 & $22 \mathrm{Ag} 026$ & 4.32 & 3.48 & -4.08 \\
\hline & $t s s-3 m$ & M4 & 0.00 & 04CG035 & 4.34 & 16.29 & 10.69 \\
\hline & $t s s-4 m$ & M1 & 29.18 & $12 \mathrm{CY} 062$ & 3.73 & 6.39 & -6.34 \\
\hline & $t s s-5 m$ & $\mathrm{M} 2 \mathrm{a}$ & 87.19 & $05 \mathrm{Bg} 131$ & 5.73 & 4.76 & -4.79 \\
\hline \multicolumn{8}{|c|}{ Total titrable acidity (\% malic acid) } \\
\hline & $t t a-1 f$ & F14 & 3.00 & $12 \mathrm{Ab} 188$ & 3.65 & 11.35 & -17.00 \\
\hline & $t t a-2 f$ & $\mathrm{~F} 12$ & 1.00 & $26 \mathrm{CB} 045$ & 3.17 & 4.23 & -11.58 \\
\hline & $\operatorname{tta}-3 f$ & F6 & 48.73 & $22 \mathrm{Ab} 094$ & 8.42 & 4.17 & 12.16 \\
\hline & $t t a-4 m$ & M4 & 31.91 & 20Bg011 & 4.85 & 13.08 & -17.95 \\
\hline & $t t a-5 m$ & M13 & 16.17 & $01 \mathrm{Bb} 245$ & 3.67 & 7.66 & 16.71 \\
\hline & $t t a-6 m$ & M11 & 1.00 & $21 \mathrm{CB} 024$ & 4.95 & 5.53 & 15.69 \\
\hline \multicolumn{8}{|c|}{ Vitamin C (mg/100g) } \\
\hline & $v c-1 f$ & $\mathrm{~F} 2$ & 67.83 & $02 \mathrm{CB} 110$ & 3.73 & 15.36 & 20.76 \\
\hline & $v c-2 f$ & $\mathrm{~F} 4$ & 108.48 & $13 \mathrm{Ab} 032$ & 4.63 & 11.65 & 16.19 \\
\hline & $v c-3 m$ & M17 & 0.00 & Aocc11 & 3.31 & 9.44 & 14.49 \\
\hline & $v c-4 m$ & M14 & 0.00 & $13 \mathrm{Bb} 220$ & 3.74 & 9.19 & 14.19 \\
\hline
\end{tabular}

${ }^{1}$ QTL position based on the region with maximum LOD score. ${ }^{2} \mathrm{R}^{2}$ : percentage of the total phenotypic variation explained by the marker close to the QTL. ${ }^{3} \mathrm{PhE}$ : phenotypic effect. 
QTL detection for physicochemical characteristics of cashew apple

F1

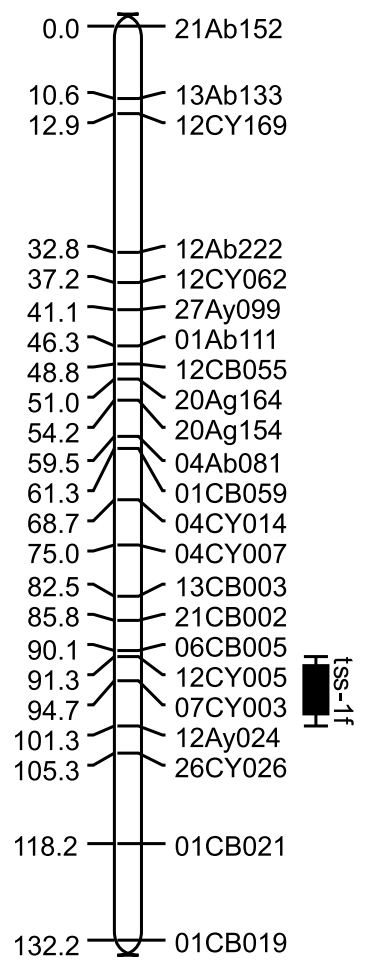

F6

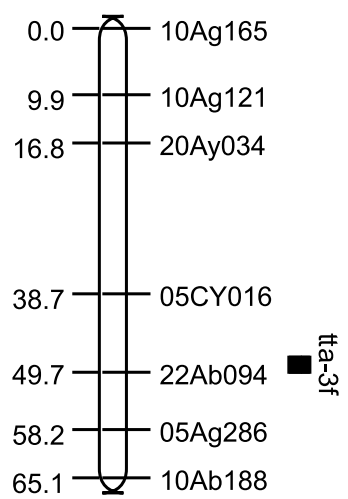

F2

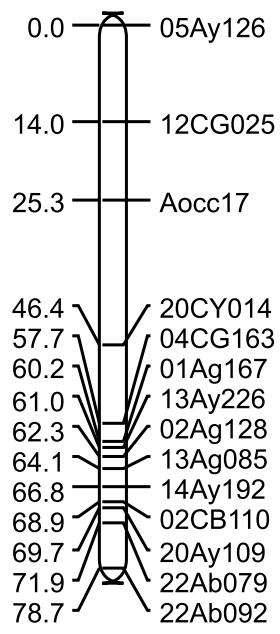

F3

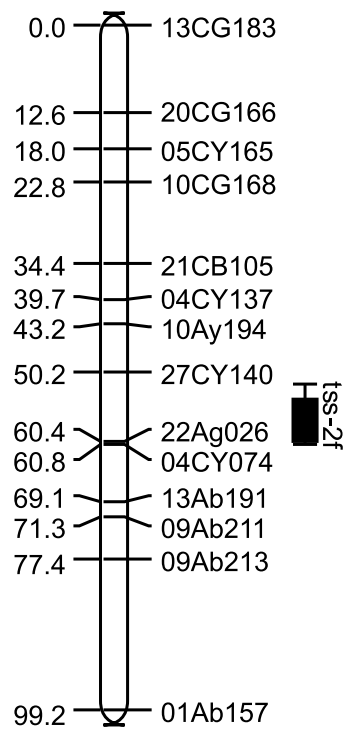

F4

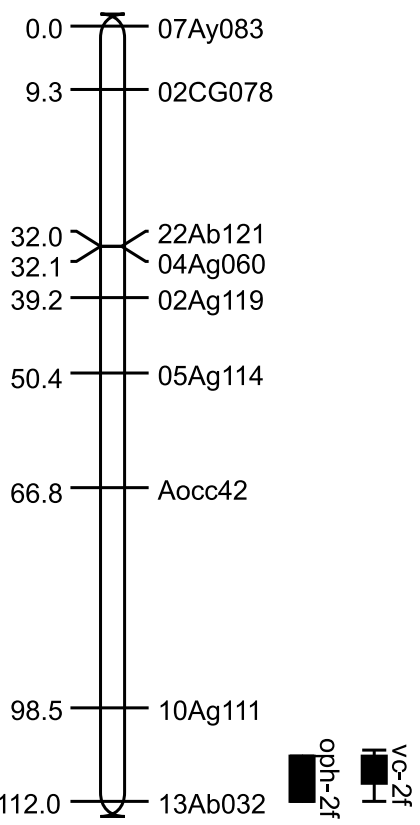

F12

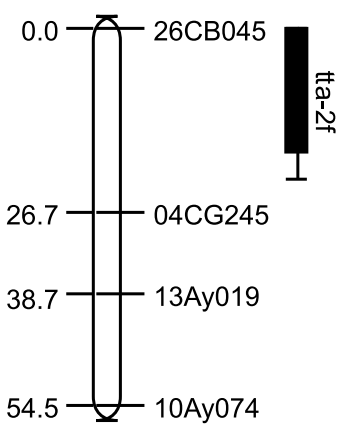

F14

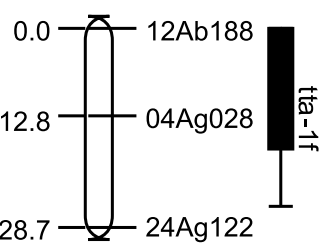

Figure 2. Position of QTL indentified for peduncle quality in the linkage map of the female parent - CCP 1001. On the right and left of the linkage group is the marker identification and its position (cM), respectively. Vertical bars and line segments on the right side of the linkage group define the confidence intervals at a level of $95 \%$. oph: oligomeric phenolics; tss: total soluble solids; tta: total titrable acidity; vc: vitamin $\mathrm{C}$. 
FHC Santos et al.

M1

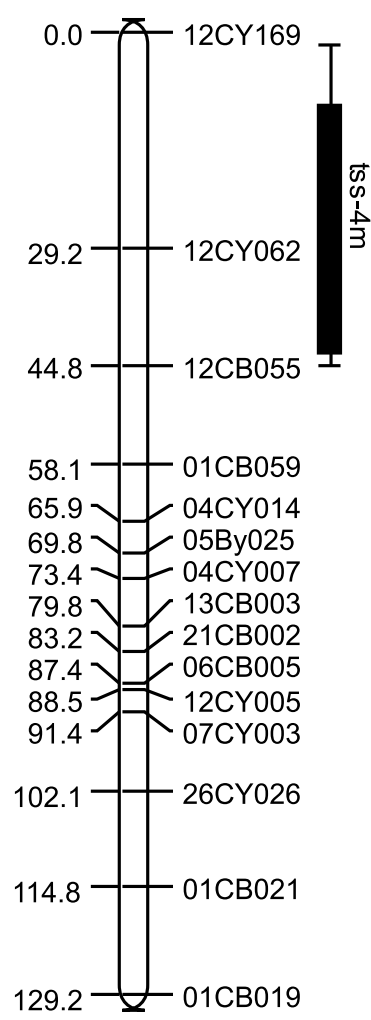

M13

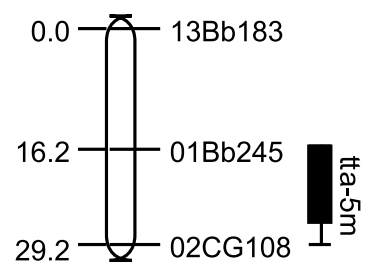

M2a

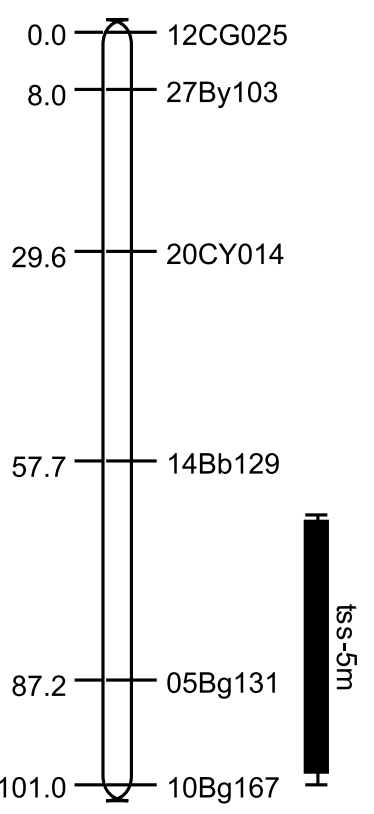

M4

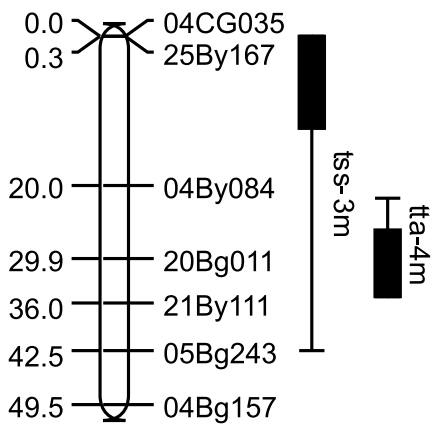

M11

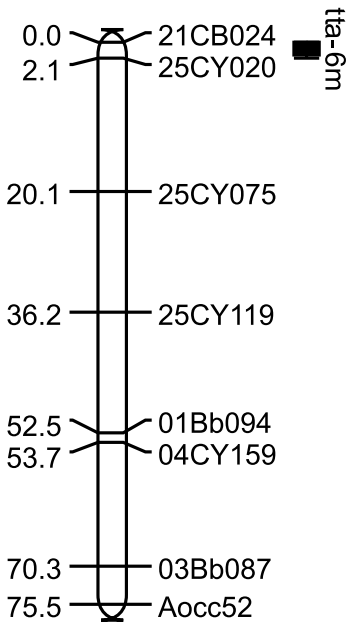

M14

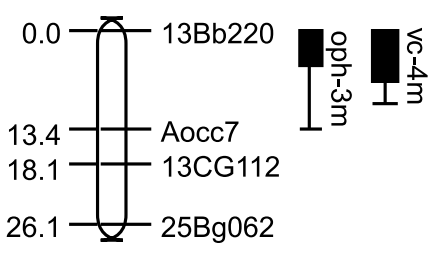

M17

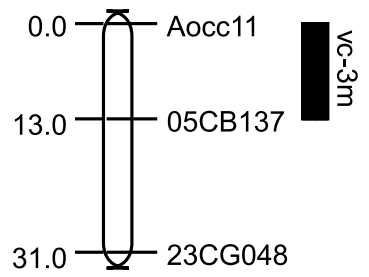

Figure 3. Position of QTL indentified for peduncle quality in the linkage map of the male parent - CP 96. On the right and left of the linkage group is the marker identification and its position (cM), respectively. Vertical bars and line segments on the right side of the linkage group define the confidence intervals at a level of $95 \%$. oph: oligomeric phenolics; tss: total soluble solids; tta: total titrable acidity; vc: vitamin $\mathrm{C}$. 


\title{
Deteç̧ão de QTL para caracteres físico-químicos do pedúnculo de caju
}

\begin{abstract}
RESUMO - A identificação de locos que controlam características quantitativas (QTLs) e a seleção assistida por marcadores têm despertado grande interesse em programas de melhoramento visando à qualidade dos frutos. Objetivou-se com este estudo identificar QTLs relacionados à qualidade do pedúnculo de caju. As características físico-químicas fenólicos oligoméricos, sólidos solúveis totais, acidez total titulável e vitamina C foram avaliadas em cajus da população mapeada. A detecção dos QTLs foi realizada utilizando as metodologias de mapeamento de intervalo e mapeamento de QTLs múltiplos. Os resultados demonstraram elevada variação fenotípica na geração $F_{1}$ segregante para todos os caracteres. Foram identificados 18 QTLs associados à qualidade do pedúnculo, sendo três para fenólicos oligoméricos, cinco para sólidos solúveis totais, seis para acidez total titulável e quatro para vitamina C. Os QTLs têm potencial para seleção assistida por marcadores devido apresentarem os maiores efeitos fenotípicos e contribuições para a variação fenotípica.
\end{abstract}

Palavras-chave: Anacardium occidentale, melhoramento genético, qualidade do pedúnculo, marcadores.

\section{REFERENCES}

Alzate-Marin AL, Cervigni GDL, Moreira MA and Barros EG (2005) Seleção assistida por marcadores moleculares visando ao desenvolvimento de plantas resistentes a doenças, com ênfase em feijoeiro e soja. Fitopatologia Brasileira 30: 333 342 .

Anderson JA, Chao S and Liu S (2007) Molecular breeding using a major QTL for fusarium head blight resistance in wheat. Crop Science 47: 112-119.

AOAC. Association of Official Analytical Chemistry (1992) Official methods of Analysis of the Association of Official Analytical Chemistry. $11^{\text {th }}$ ed., AOAC, Washington, $1115 \mathrm{p}$.

Barros LM, Paiva JR, Cavalcanti JJV and Araújo JPP (2002) Cajueiro. In Bruckner $\mathrm{CH}$ (ed.) Melhoramento de fruteiras tropicais. Editora UFV, Viçosa, p. 159-176.

Broman KW (2001) Review of statistical methods for QTL mapping in experimental crosses. Lab Animal 30: 44-52.

Cavalcanti JJV and Wilkinson MJ (2007) The first genetic maps of cashew (Anacardium occidentale L.). Euphytica 157: 131143.

Crisóstomo JR, Cavalcanti JJV, Barros LM, Alves RE, Freitas JG and Oliveira JN (2002) Melhoramento do cajueiro-anãoprecoce: avaliação da qualidade do pedúnculo e a heterose dos seus híbridos. Revista Brasileira de Fruticultura 24: 477 480 .

Cristofani M, Machado MA and Grattapaglia D (1999) Genetic linkage maps of Citrus sunki Hort. ex. Tan. and Poncirus trifoliata (L.) Raf. and mapping of citrus tristeza virus resistance gene. Euphytica 109: 25-32.

Cruz CD (2001) Programa Genes-versão Windows: aplicativo computacional em genética e estatística. Universidade Federal de Viçosa, Viçosa.
Fanizza G, Lamaj E, Costantini L, Chaabane R and Grando MS (2005) QTL analysis for fruit yield components in table grapes (Vitis vinifera). Theoretical and Applied Genetics 111: 658664.

IAL. Instituto Adolfo Lutz (1985) Normas analíticas, métodos químicos e físicos para análise de alimentos. $2^{\text {nd }} \mathrm{ed}$., IAL, São Paulo, 371p.

Jansen RC (1993) Interval mapping of multiple quantitative trait loci. Genetics 135: 205-211.

Jansen RC (1994) Controlling the type I and type II errors in mapping quantitative trait loci. Genetics 138: 871-881.

Jansen RC and Stam P (1994) High resolution of quantitative traits into multiple loci via interval mapping. Genetics 136: 1447-1455.

Kearsey MJ and Farquhar AGL (1998) QTL analysis in plants; where are we now. Heredity 80: 137-142.

Kenis K and Keulemans J (2005) Genetic linkage maps of two apple cultivars (Malus x domestica Borkh.) based on AFLP and microsatellite markers. Molecular Breeding 15: 205-219.

Kenis K, Keulemans J and Davey MW (2008) Identification and stability of QTLs for fruit quality traits in apple. Tree Genetics \& Genomes 4: 647-661.

Lander ES and Botstein D (1989) Mapping Mendelian fators underlying quantitative trait using RFLP linkage maps. Genetics 121: 185-199.

Lecomte L, Duffé P, Buret M, Servin B, Hospital F and Causse M (2004) Marker-assisted introgression of five QTLs controlling fruit quality traits into three tomato lines revealed interactions between QTLs and genetic backgrounds. Theoretical and Applied Genetics 109: 658-668. 
FHC Santos et al.

Melo LC, Santos JB and Ferreira DF (2002) Mapping and stability of QTLs for seed weight in common beans under different environments. Crop Breeding and Applied Biotechnology 2: $227-236$.

Paterson AH, Damon S, Hewitt JD, Zamir D, Rabinowitch HD, Lincoln SE, Lander ES and Tanksley SD (1991) Mendelian factors underlying quantitative traits in tomato - comparison across species, generations, and environments. Genetics 127: $181-197$.

Quilot B, Wu BH, Kervella J, Genard M, Foulongne M and Moreau K (2004) QTL analysis of quality traits in an advanced backcross between Prunus persica cultivars and the wild relative species P. davidiana. Theoretical and Applied Genetics 109: 884897.

Reicher F, Sierakowski MR and Corrêa JBC (1981) Determinação espectrofotométrica de taninos pelo reativo, fosfotúngsticofosfomomolíbdico. Arquivos de Biologia e Tecnologia 24: 401-411.

Ribeiro AO, Bearzoti E and Sáfadi T (2005) QTL mapping of Poisson traits: a simulation study. Crop Breeding and Applied Biotechnology 5: 310-317.
Santos FHC, Cavalcanti JJV and Silva FP (2010) Detection of quantitative trait loci for physical traits of cashew apple. Crop Breeding and Applied Biotechnology 10: 101-109.

Singh S, Sidhu JS, Huang N, Vikal Y, Li Z, Brar DS, Dhaliwal HS and Khush GS (2001) Pyramiding three bacterial blight resistance genes (xa5, xa13 and xa21) using marker-assisted selection into indica rice cultivar PR106. Theoretical and Applied Genetics 102: 1011-1015.

Strohecker R and Henning HM (1967) Analisis de vitaminas: métodos comprobados. Paz Montalvo, Madrid, 428p.

Stuber CW, Polacco M and Senior LM (1999) Synergy of empirical breeding, marker-assisted selection, and genomics to increase crop yield potential. Crop Science 39: 1571-1583.

Van Ooijen JW (2004) MapQTL 5: software for mapping of quantitative trait loci in experimental populations. Kyazma B.V., Wageningen.

Voorrips RE (2002) MapChart: software for the graphical presentation of linkage maps and QTLs. Journal of Heredity 93: $77-78$. 